№. 4409 May 1, 1954

\section{Earthquakes during January}

Earthquakes caused minor property damage on January 12 near Wheeler Ridge, California (magnitude 6), and on January 25 in the island of São Miguel in the Azores. Earthquakes were also reported as 'felt' on January 2 at Arenas del Rey in Spain; on January 17 in Central Honshu, Japan; on January 18 near the west coast of Greece ; and on January 27 and 28 near the coast of Guerrero, Mexico. The greatest earthquakes during the month were on January 12 and 13 (magnitudes 7 and $7 \frac{1}{4}$ ) off the South Island of New Zealand; and other shocks of magnitude 6 and greater occurred, in addition to those mentioned, on January 1 in the Sawoe Sea, on January 20 in the Pacific Ocean south of Mexico, and on January 21 in Kenya. Reports have been received from individual stations at Durham, Lwiro (Belgian Congo), Pasadena, Strasbourg, Toledo and Uccle; and from the United States Coast and Geodetic Survey in co-operation with Science Service and the Jesuit Seismological Association.

\section{The Night Sky in May}

NEw moon occurs on May 2d. 20h. 22m., U.T., and full moon on May $17 \mathrm{~d}$. 21h. $47 \mathrm{~m}$. The following conjunctions with the moon take place: May 4d. 13h., Venus $3^{\circ}$ S.; May 5d. 20h., Jupiter $2^{\circ}$ S.; May 16d. 07h., Saturn $8^{\circ}$ N.; May 21d. 08h., Mars $1^{\circ} \mathrm{S}$. In addition to these conjunctions with the moon, Mercury is in conjunction with Aldebaran on May 19d. 11h., Mercury being $7 \cdot 2^{\circ} \mathrm{N}$.; Venus is in conjunction with Jupiter on May 23d. 12h., Venus $1 \cdot 5^{\circ} \mathrm{N}$.; and Mercury is in conjunction with Jupiter on May 31d. 19h., Mercury $2 \cdot 2^{\circ}$ N. Mercury, in superior conjunction on May 8 , is too close to the sun to be seen in the early part of the month ; on May 15 and 31 it sets at $20 \mathrm{~h} .25 \mathrm{~m}$., and $22 \mathrm{~h}$., respectively, but in the former case this is only 40 minutes after sunset. Its close approach to Jupiter on May 31 has already been pointed out. Venus is an evening star, its times of setting on May 1, 15 and 31 being 21 h. $25 \mathrm{~m}$., $22 \mathrm{~h} .05 \mathrm{~m}$. and $22 \mathrm{~h}$. $30 \mathrm{~m}$., respectively. The visible portion of its illuminated disk varies from 0.922 to 0.855 , and its stellar magnitude from $-3 \cdot 3$ to $-3 \cdot 4$. Mars rises at $0 \mathrm{~h} .10 \mathrm{~m}$., $23 \mathrm{~h}$. $30 \mathrm{~m}$. and 22h. 35m. on May 1, 15 and 31, respoctively. It has an eastward motion in the constellation Sagittarius until May 23 when it is stationary, after which its motion is westward. Jupiter sets at $23 \mathrm{~h}$. 15m., $22 \mathrm{~h} .30 \mathrm{~m}$. and $21 \mathrm{~h} .45 \mathrm{~m}$. on May 1,15 and 31 , respectively. Its eastward movement from east of $\zeta$ Tauri to west of $\eta$ Geminorum is easily detected. Saturn rises at $18 \mathrm{~h} .35 \mathrm{~m}$., $17 \mathrm{~h} .35 \mathrm{~m}$. and $16 \mathrm{~h} .25 \mathrm{~m}$. at the beginning, middle and end of the month, respectively, and is close to $x$ Virginis; it can be seen until the early morning hours. No occultations take place during May. The $\eta$ Aquarid meteors are active at the beginning of the month, attaining a maximum about May 6 ; the radiant is at R.A. $22 \mathrm{~h}$. $24 \mathrm{~m}$., Dec. $-1^{\circ}$, very close to $\eta$ Aquarii, from which the shower derives its name. For a long time it was believed that it was associated with the debris of Halley's Comet, but there is now some doubt about this.

\section{Announcements}

THE Royal Meteorological Society announced the following awards at the annual general meeting held on April 28: Buchan Prize for the period 1949-53 to Dr. R. S. Scorer for his outstanding contributions to dynamical meteorology; Hugh Robert Mill Medal and Prize for 1954 to Mr. C. K. M. Douglas, for his outstanding contributions to our knowledge of tho causes of rain. Darton prize awards were also announced as follows: First Prize, for 1953, Messrs. B. J. Mason and R. Ramanadham. Canadian Prizes for 1953 : First Prize, Dr. W. L. Godson; Second Prize, Mr. G. W. Robertson.

The Worshipful Company of Clockmakers (Candlewick House, 116 Cannon Street, London, E.C.4) has decided to institute an award for outstanding achievement in the field of horology. It will take the form of a gold medal, to be known as the Tompion Medal of the Worshipful Company of Clockmakers, and will be awarded, without regard to nationality, not more than once a year.

Colonel S. J. M. Autd has been elected president of the Institute of Petroleum for the year 1954-55. Colonel Auld was previously president of the Institute in $1937-38$.

Mr. K. B. Ross, who until 1951 was general refineries manager for the Anglo-Iranian Oil Co. at. Abadan, and has since then been on the Board of Messrs. Costain-John Brown, Ltd., has been appointed director of production in the Industrial Group of the Department of Atomic Energy at Risley. Mr. P. T. Fletcher, chief engineer of the Ministry of Works, has been appointed deputy director (engineering services) in the Industrial Group.

THE following appointments have been made in the University of London : Dr. F. E. Camps, lecturer at the London Hospital Medical College, to the parttime University readership in forensic medicine tenable at that College; Dr. G. E. Francis, senior lecturer at St. Bartholomew's Hospital Medical College, to the University readership in biochemistry tenable at that College.

THE Committee of Privy Council for Agricultural Research and Nature Conservation has appointed Mr. David Lowe, a prominent Scottish horticulturist, and, after consultation with the President of the Royal Society, Mr. J. N. Ritchie, chief veterinary officer of the Ministry of Agriculture and Fisheries, to fill two vacancies on the Agricultural Research Council.

Following the resignation of Mr. A. G. Peacock, for seven years secretary of the Scientific Instrument Manufacturers' Association, Mr. E. D. Hart, for many years with Marconi Instruments, Ltd., and lately with the Equipment Division of Mullard, Ltd., has been appointed deputy director of the Association. Miss G. F. Moss, formerly clerk to the Council, has now taken the position of secretary.

THE Section of Mathematical Statistics of the Australian Commonwealth Scientific and Industrial Research Organization has now become the Division of Mathematical Statistics, with headquarters in Adelaide, and its officer-in-charge, Dr. E. A. Cornish, is now chief of the new Division. The main task of the Division is to provide research workers of the Organization with special help in planning their researches and analysing and interpreting their experimental results.

Frratum. In the communication entitled "Proposal for a New Atther-Drift Experiment", by Dr. L. Essen (Nature, April 17, p. 734), line 23, for " \pm 1 part in $10^{8}$ " read " \pm 1 part in $10^{10}$ ". 